NBER WORKING PAPER SERIES

\title{
TAXING CONSUMPTION AND OTHER SINS
}

James R. Hines Jr.

Working Paper 12730

http://www.nber.org/papers/w12730

\author{
NATIONAL BUREAU OF ECONOMIC RESEARCH \\ 1050 Massachusetts Avenue \\ Cambridge, MA 02138 \\ December 2006
}

I thank Tomislav Ladika for outstanding research assistance, and Kathryn Dominguez, Andrei Shleifer, Timothy Taylor, and Michael Waldman for extremely helpful comments on an earlier draft of this paper. The views expressed herein are those of the author(s) and do not necessarily reflect the views of the National Bureau of Economic Research.

(C) 2006 by James R. Hines Jr.. All rights reserved. Short sections of text, not to exceed two paragraphs, may be quoted without explicit permission provided that full credit, including $\odot$ notice, is given to the source. 
Taxing Consumption and Other Sins

James R. Hines Jr.

NBER Working Paper No. 12730

December 2006

JEL No. H20,H23,H71

\begin{abstract}
$\underline{\text { ABSTRACT }}$
Throughout American history, the U.S. federal and state governments have imposed excise taxes on commodities such as alcohol and tobacco (and more recently, gasoline and firearms). Rates of such "sin" taxation, and consumption taxation broadly (including sales taxes and value-added taxes), are currently much lower in the United States than they are in Europe, Japan, and other affluent parts of the world. In part, this reflects relative government sizes, but that is not the whole story, since even controlling for total tax collections, levels of national income, government decentralization, and openness to international trade, the United States imposes unusually low excise and consumption taxes. As a result, the United States relies to a much greater degree than other countries on personal and corporate income taxes, thereby affording fewer opportunities to use the tax system to protect individuals and the environment by discouraging the consumption of "sinful" commodities, and instead simply discouraging saving and investment.
\end{abstract}

James R. Hines Jr.

Department of Economics

University of Michigan

343 Lorch Hall

611 Tappan Street

Ann Arbor, MI 48109-1220

and NBER

jrhines@umich.edu 


\section{Introduction}

Federal and state governments in the United States use income and payroll taxes as their primary tools to collect revenue. In the rest of the world, governments also use income and payroll taxes, but rely much more heavily than does the United States on taxing consumption. Consumption taxes take many forms, including general sales taxes, value-added taxes, and excise taxes on the consumption of specific items including gasoline, alcohol, tobacco products, firearms, air travel, telephone communication, and others.

The U.S. government does not use a value-added tax (VAT), making the United States unique among high-income countries and a rarity in the larger world. As of 2004, at least 134 countries rely on VATs as a substantial source of funding. VATs are sophisticated forms of sales taxes in which taxes are withheld by businesses according to value added at every stage of production. American states do impose sales taxes on broad categories of consumer purchases, but state governments are considerably smaller than national governments, and their sales tax rates are very low compared to the VAT rates used in the rest of the world.

The United States also imposes unusually low excise taxes even after controlling for total tax collections, which are lower in the United States than they are in most highincome countries. The deliberate social engineering that underlies the selection of certain commodities for unusually high rates of taxation appeals less to Americans than to residents of other countries. Moreover, the "sin" taxes on purchases of commodities such as gasoline, alcohol, tobacco, and firearms are not primarily imposed by the U.S. 
government for collecting substantial tax revenue for general spending purposes although excise taxes have been used that way in the past. Instead, excise taxes are intended to discourage consumption of the specific taxed goods, thereby preventing some potential customers from contributing to pollution, traffic congestion, injury, and poor health. As one example, the U.S. tax on ozone-depleting chemicals is intended to provide incentives to discourage use of these chemicals. In addition, these sin taxes raise revenue that the government can use for targeted purposes like funding highway improvements, medical care, and law enforcement efforts that combat some of the consequences of gasoline, alcohol, tobacco, and firearms. For example, the federal tax on sport fishing equipment is intended to raise money to cover costs that the government incurs in supporting the taxed activity.

The absence of value-added taxation in the United States, together with the very low rates of U.S. excise taxation, requires the U.S. government to rely heavily on income taxes to finance its activities. There are three consequences of this reliance on income taxes. First, U.S. excise tax policy does relatively little to discourage the consumption of particular goods that damage the environment or the individuals concerned. Second, it is difficult to tailor the income tax system to charge individuals even roughly appropriate amounts for their use of specific government services such as roads and health care. Third, and perhaps most important, is that reliance on income taxation imposes a higher tax burden on capital income than would be the case if the government instead made more extensive use of consumption taxes. Capital income taxes discourage saving and investing, and, since the effects of capital income taxes compound over time, these taxes are among the most distortionary of all taxes. Even a very low rate of capital income 
taxation significantly increases the cost of consuming in the future relative to consuming today, and this relative price distortion grows as the saving horizon increases. While it is perhaps unfair to place the "sin" of general consumption in quite the same category as the sin of consuming alcohol or tobacco, or other potentially harmful substances, the very low U.S. saving rate, and its consequences in reduced prosperity for the elderly and for future generations, makes marginal consumption look relatively sinful when compared to greater saving. The inefficiency associated with taxing capital income increases with an economy's exposure to international capital flows, since rising international mobility makes a country's capital stock more sensitive to taxation, suggesting that the cost of not making more extensive use of consumption taxes has been rising over time.

\section{Consumption Taxes in the United States}

The primary consumption taxes used by the U.S. federal government are excise taxes. Consumption taxes used by U.S. states include a combination of excise and sales taxes. State governments rely more heavily on consumption taxes than does the federal government, but the much smaller sizes of state governments implies that the net consumption tax burden in the United States remains rather modest.

\section{Federal Excise Taxation}

There is no federal value-added tax, no federal sales tax, and only a rather modest assortment of federal excise taxes. Table 1 displays tax collections from major federal

excise taxes in 2004. In the 2004 federal budget, all excise taxes together collected $\$ 71.8$ billion, representing 4 percent of total revenues of $\$ 1,797$ billion. The federal tax on gasoline and related products accounts for $\$ 32.6$ billion, or 45 percent of total excise tax 
collections, with the remainder consisting principally of federal taxes on tobacco (11 percent of total excise taxes), air travel ( 9 percent), telephone service ( 8 percent) and various forms of alcohol (12 percent).

Earlier American history includes periods in which federal excise taxes were more important sources of revenue. In order to finance debts incurred in the Revolutionary War and for which tariff revenues were insufficient, Congress in 1791 and 1794 introduced excise taxes on tobacco and snuff, refined sugar, distilled spirits, carriages, and property sold at auction (Dewey, 1907, pp. 105-109). Some of these taxes, including a subsequent 1797 stamp tax on the execution of various legal documents, replicated the unpopular taxes that the British government had imposed on the American colonies. Indeed, in a 1774 address attempting to enlist support from residents of Quebec, the Continental Congress had argued that under British rule they were subject "to the impositions of EXCISE, the horror of all free states" (Hu, 1950, p. 11), expressing a view that apparently changes with perspective.

The new federal excises were not warmly embraced by all taxpayers. The tax on distilled spirits drew fierce opposition in North Carolina and particularly in western Pennsylvania, where it prompted open defiance, riots, and mob violence that included destroying the property of those complying with the tax and tarring and feathering of federal tax collectors. By 1794, the Whiskey Rebellion required President George Washington to send troops to Pennsylvania to suppress the insurrection and arrest its participants (Hu, 1950, pp. 19-28). The government of Thomas Jefferson abolished all federal excises in 1802, balancing its budget instead with tariffs, land sales, and military spending cuts (Dewey, 1907, p. 120). 
The War of 1812 required new revenue sources, including the older excise taxes and new ones on gold, jewelry, silverware and watches, but when the war concluded, Congress in 1817 repealed all federal excises (Dewey, 1907, pp. 139-140). From 1817 until the outbreak of the Civil War in 1861, the federal government was funded exclusively by land sales and tariffs. At the start of the Civil War, the federal government reinstituted its old excise taxes, and by 1862 had added new excises on playing cards, feathers, patent medicines, billiard tables, leather, telegrams, yachts, and a host of other luxuries (Dewey, 1907, p. 301). The federal government also introduced a personal income tax, despite the U.S. Constitution's prohibition against federal income taxation, not to mention taxpayer outrage at its confiscatory top tax rate of 5 percent. The income tax and many of the new excise taxes were repealed following the Civil War, only to reappear briefly in the 1890s, when the need to finance the Spanish-American war led at the end of the decade to the doubling of federal taxes on beer and tobacco, and adoption of excise taxes on exotic new products, among them chewing gum and telephone calls (Dewey, 1907, p. 466).

Passage of the $16^{\text {th }}$ amendment to the U.S. Constitution in 1913 permitted the federal government to levy a personal income tax, which quickly became the mainstay of federal revenues, though it did not entirely supplant federal excise taxes. Prohibition together with excise tax reductions dealt a serious blow to federal excise tax collections between 1920 and 1933, but the repeal of Prohibition in 1933, along with an expansion of other federal excises on Depression-era luxuries (including gasoline, refrigerators, radios, phonograph records, candy and chewing gum, matches, furs, jewelry, cameras, and soft drinks), helped to finance expanded federal spending. Indeed, federal excise taxes 
collected more than 15 percent of federal revenue in 1933 (Francis, 2000), and the repeal of Prohibition alone made feasible federal alcohol tax collections in the range of $\$ 500$ million to $\$ 600$ million per year during the 1930 s, enough to finance more than a quarter of the roughly $\$ 2$ billion a year that Gruber and Hungerman $(2005$, p. 10) estimate that the federal government spent on all New Deal relief programs combined.

The vastly broadened scope of the federal government during and following World War II required substantially higher income taxes, but certain excise taxes remained. The federal gasoline tax, introduced in 1933, discourages driving and thereby reduces pollution and traffic congestion; furthermore, since 1956, federal gas tax revenues have been parked in the Highway Trust Fund, which finances the construction and maintenance of interstate highways and urban mass transit projects. Indeed, because the federal gas tax serves in part as a fee for the use of federal highways, non-highway business and farm use of gasoline and diesel fuel, and household non-highway use of diesel fuel, are exempt from federal taxes. Buyers who commit not to drive on interstate highways are entitled to purchase untaxed diesel fuel, to which the government adds a strong dye that identifies any culprits caught on highways (by federal tax inspectors) with untaxed fuel in their tanks. But of course even off-highway use of gasoline and diesel fuel produces pollution.

Environmental concerns prompted the federal government to introduce excise taxes on ozone-depleting chemicals in 1989, following the 1987 Montreal Protocol, an international agreement intended to protect the Earth's ozone layer. The Montreal Protocol committed the United States to reduce production of various ozone-depleting chemicals by 50 percent; since this might be accomplished either by restricting 
production directly or by imposing high taxes, the U.S. government decided to do both. Congress initially believed that the quantity limits would be the more restrictive of the two policies, driving up the prices of ozone-depleting chemicals, and leaving the excise tax to serve the role of a windfall profit tax on producers lucky enough to receive production quotas (Merrill and Rousso, 1991). But subsequent tax increases, together with changed market conditions, drove actual production of ozone-depleting chemicals below the quota limits (Fullerton, 1996), making federal taxes, and not the quotas, the determinants of national production levels. In practice, the rates at which different chemicals and their uses are taxed bear little resemblance to a tax finely tailored to reduce total ozone depletion, as a well-designed tax would impose much higher rates on activities more likely to release ozone-depleting chemicals into the atmosphere (Barthold, 1994), though the net result of federal taxation has certainly been in the desired direction.

The federal government imposes many other environmental excise taxes, including a tax on the sale of gas-guzzler cars (those with fuel economy averages below 22.5 miles per gallon), and taxes on other heavy road vehicles, highway-type tires, and all forms of air transportation. In an interesting twist on "sin" taxation, the federal government imposes a LUST tax of 0.1 cent per gallon on motor fuels to fund its Leaking Underground Storage Tank Trust Fund. The original idea of the LUST tax was to pay for cleanups of, yes, leaking underground fuel storage tanks, but the LUST Trust Fund collects much more revenue than it spends each year, its surplus seeping into the U.S. Treasury. The same pattern of annual surpluses for many years characterized gas taxes earmarked for interstate highways, though this pattern has reversed recently. 
Many federal excise taxes, including the taxes on motor fuels, are designed to raise revenue to finance government expenditures that promote the taxed activity. For example, the 10 percent federal tax on fishing tackle, 3 percent tax on electric outboard motors and fish-finding sonar devices, and a portion of motorboat fuel tax revenues are cast into the Aquatic Resources Trust Fund, which finances programs for boat safety and sport fish restoration. An 11 percent federal tax on rifles, shotguns, firearm ammunition, and bows and arrows, together with a more favorable 10 percent tax on pistols and revolvers, provides resources for the Wildlife Restoration Project Fund. The money in this fund is distributed to states to help them maintain ample supplies of targets by financing animal surveys and inventories, habitat research, hunter education programs, and management of the remaining wildlife populations.

\section{State Excise and Sales Taxation}

American states have used a wide variety of consumption-based taxes throughout their histories, though their heavier reliance on consumption taxes is a relatively recent phenomenon. Early taxes in American colonies were largely poll taxes, imposed on adult males with obligations that might vary by occupation; there were also import duties, land taxes, and taxes on other property, such as houses, animals and ships. Excise taxes were used most heavily by the middle Atlantic and New England colonies, though almost all colonies taxed liquor production (Ely, 1888, p. 114). New York, ever a leader in taxation, had taxes on wine and beer as early as 1650 (Sumner, 1891, p. 19), taxes on tobacco, grain, hemp, flax, butter and cheese by 1653 (Ely, 1888, p. 110), and introduced a liquor sales tax in 1713. Pennsylvania likewise had longstanding taxes on wine, rum, 
and other spirits, but some colonies started much later, such as New Hampshire, which introduced its excise taxes on wine, rum, cider and tea only in 1756.

The colonies maintained multiple revenue sources upon graduating to statehood, and over the subsequent 217 years the American states have relied on excise taxes to varying degrees. Property taxes have always served as important revenue sources, though in the twentieth century the use of income taxes expanded, and consumption taxes came into their own. By 2004, property taxes accounted for 31.5 percent of total state and local revenues, with individual income taxes raising 21.3 percent, corporate income taxes 3.3 percent, excise taxes 11.5 percent, and general sales taxes 24.2 percent.

Oregon adopted the first excise tax on gasoline in 1919, and within ten years every state had one. Since each state chooses its own gasoline tax there is inevitably variation between them, though in practice they display rough conformity. The second column of Table 2 presents 2006 state gasoline sales tax rates (inclusive of additional fees and charges) for states with the highest and lowest tax rates. The states vary from a high tax rate of 32.9 cents per gallon in Wisconsin to lows of 8 cents per gallon in Alaska and 14 cents in Wyoming. States have taxed tobacco for much longer than they have gasoline, and by 2006 managed to acquire considerable diversity in their rates, as displayed in column 4 of Table 2 . Rhode Island's $\$ 2.46$ per pack tax on cigarettes, and New Jersey's \$2.40 tax, are breathtaking compared to the 7 cent tax per pack in South Carolina, the 17 cent tax per pack in Missouri, and 18 cent tax per pack in Mississippi.

The U.S. federal government never taxed general sales, and the U.S. state governments adopted such taxes only within the last century. In this, the American states 
followed the rest of the world. As of 1918, only Germany among large countries imposed a sales tax, and that at a paltry 0.1 percent rate; but the postwar financial difficulties of European governments prompted several of them to introduce sales taxes between 1918 and 1923. The idea had international appeal. West Virginia was the first of the U.S. states to introduce a general sales tax, doing so in 1921; it was followed by Georgia in 1929, and eleven more states in 1933, with additional states following shortly thereafter. In the case of American states, the timing reflects the impact of the Great Depression. Falling state tax revenues due to hard economic times, along with a desire to reduce property tax burdens in order to prevent tax-driven foreclosures of property owners, motivated states to look for new revenue sources that imposed burdens better tied to contemporaneous ability to pay. ${ }^{1}$ By 2006 the Depression was a distant memory, but nevertheless, all but five states -- Alaska, Delaware, Montana, Oregon, and New Hampshire -- raise significant revenue with general sales taxes.

\section{U.S. Consumption and Excise Taxation in World Perspective}

The United States taxes consumption at very low rates compared to other countries. Gasoline taxes are emblematic of this situation. As Table 2 indicates, U.S. federal taxes on unleaded gasoline are currently 18.4 cents a gallon, and states average 21.57 cents per gallon. The combined federal and state rate of 39.97 cents per gallon gives the United States the third lowest gasoline tax rate among the members of the Organisation for Economic Cooperation and Development (OECD), which includes the 30 highest per capita income countries. Column 2 of Table 3 displays excise taxes on

\footnotetext{
${ }^{1}$ Haig and Shoup (1934) review the history of sales taxation and offer a contemporaneous assessment of the forces behind the adoption of sales taxes in American states.
} 
unleaded gasoline in OECD countries in 2003, rates that do not include VATs, general sales taxes, or other charges that apply to general commodities. Gasoline taxes in the United Kingdom are 6.7 times higher than in the United States, and there is not a single country in Europe whose gasoline taxes are less than 2.75 times higher than those in the United States. Japan's tax rate is more than four times higher than the U.S. rate, and Korea's 5.5 times higher. Only Canada and Mexico among OECD countries have lower gasoline taxes than the United States. While it does not necessarily follow that the rest of the world is right in taxing gasoline heavily, while North America is wrong, these comparisons do show that the United States and its North American neighbors differ sharply from most other countries.

Gasoline is not the only fuel that the United States taxes very lightly. The U.S. average (federal plus state) tax rate of $\$ 9.20$ per liter of distilled alcohol ranks $19^{\text {th }}$ out of the 26 OECD countries for which comprehensive data are available for 2003. Column 4 of Table 3 presents these average tax rates. The Scandinavian countries, Ireland, Turkey, and the United Kingdom all tax hard alcohol at rates more than 3.4 times that of the United States, whereas only the Czech Republic, Spain, Canada, Italy, the Slovak Republic, and Hungary have lower tax rates. National tax rates on wine, beer, tobacco, and other products can be more difficult to compare across countries, since the rates vary with prices and product attributes, but any of these comparisons classifies the United States as a low tax country. 


\section{Composition of total tax revenues}

One of the reasons why U.S. excise tax rates are low is that the United States has a smaller government sector than do most OECD countries, so all U.S. tax rates tend to look low by comparison. One way to control for government size differences among countries is to consider the relative contributions of different revenue sources. However, such comparisons do little to change the impression produced by simple examination of tax rates.

It is instructive to compare ratios of revenues from specific taxes to total tax collections for OECD countries in 2000. The numerator in this ratio includes revenues from excise taxes and other charges that are product-specific, including customs duties and taxes on insurance and certain financial operations. For the United States, federal plus state and local revenues from specific taxes represent 6.3 percent of total tax collections, the lowest of any OECD country (OECD, 2005, p. 25). Members of the European Union collected an average of 10.2 percent of their government revenue from specific taxes, and for the OECD as a whole (including the United States) the average was 11.7 percent, close to double the corresponding U.S. figure.

American exceptionalism is likewise evident in environmental taxation, the intensity of which can be measured by ratios of revenues from environmental taxes to total tax collections in 2000. The numerator of this ratio includes tax collections (defined to exclude user fees) on energy products, motor vehicles and other transportation, waste management, ozone-depleting substances, and what the OECD (2005) refers to as “other." In 2000 the United States collected only 3.4 percent of its total government 
revenues from environmental taxes, making its tax system the least environmentally oriented of any OECD country. The next lowest ratios are Canada, at 3.8 percent, and New Zealand, at 4.7 percent; the OECD average (including the United States) is 5.5 percent, and the European Union average is 6.7 percent, double that of the United States (OECD, 2005, p. 111). Even these comparisons understate the extent to which the U.S. tax system differs from other countries in effectively protecting the environment, since the relatively small size of the U.S. public sector means that tax differences do correspondingly little to change the relative prices of activities that harm the environment.

\section{Value-Added Taxes}

Value-added taxation, as practiced by most of the world, is simply a form of general sales taxation. However, instead of being collected exclusively from the end-user, as with U.S. state-level sales taxes, a VAT is collected from businesses as they sell their output to intermediate and final buyers. Each firm first calculates the value-added tax on its total revenues, and then takes a tax credit for taxes paid by firms from whom they bought any intermediate inputs. Because each firm has an incentive to report fully what it purchased from other firms, the VAT facilitates tax enforcement by requiring purchasers to produce records of sales by other firms in order to claim VAT credits. Also, the crediting aspect of value-added taxation ensures that sales taxes are not compounded on goods that require multiple stages of production. As a result, VATs are efficient and effective revenue collection devices, making them popular with governments, though perhaps less so with some taxpayers. Metcalf (1995) and Ebrill et al. (2001) describe the virtues and practice of value-added taxation. 
The widespread adoption of value-added taxes is the major tax event of the second half of the twentieth century. As late as 1966, only two countries (the Côte d'Ivoire and Senegal) had introduced VATs; by 1985, 35 countries had done so; and in 2004, 134 countries collected significant tax revenue with VATs. Every OECD country other than the United States uses VATs; the second column of Table 4 displays their basic VAT rates during 2000. The average VAT rate in OECD countries other than the United States is 17.7 percent, though there is considerable variation, with Denmark, Hungary, and Sweden at the high end imposing 25 percent VAT rates, and Japan, Canada, and Switzerland at the low end all using VAT rates in the 5.0 - 7.5 percent range.

The modest rates at which U.S. states tax general sales, together with the absence of a VAT, implies that the United States taxes general consumption at lower rates than any other OECD country. Column 4 of Table 4 presents ratios of revenues from general consumption taxes to total tax collections for OECD countries in 2000. The general consumption tax revenues in the numerator of this ratio include those raised by VATs, the roughly equivalent goods and services taxes used by some countries, and general sales taxes; this category excludes excise taxes and other specific taxes. In the United States, 7.6 percent of all tax revenue comes from general consumption taxes, the lowest fraction in the OECD; the next lowest fractions belong to Japan, at 8.9 percent, Australia, at 12.1 percent, and Switzerland, at 13.1 percent. The average contribution of general consumption taxes to total tax revenue in the European Union is 18.4 percent, and the OECD average is 18.5 percent. While the difference between the 7.6 percent U.S. ratio of general consumption taxes to total taxes and the OECD average of 18.5 percent may 
appear undramatic in the grand scheme of government finance, it is worth bearing in mind that this constitutes a much larger percentage difference in fractions of government revenue other than payroll taxes and other social insurance contributions.

\section{How Anomalous is U.S. Consumption Tax Policy?}

U.S. consumption tax policy differs sharply from the policies adopted by other countries. To what extent are these differences explainable across countries by factors such as differences in per capita income, government centralization, and openness of the economy?

Table 5 presents univariate regressions in which the dependent variables are measures of the extent to which countries rely on consumption taxes in raising government revenue. The dependent variable in the regressions presented in columns 1-3 is the ratio of excise tax collections to total tax revenue, the sample consisting of the 26 OECD countries for which the relevant data are available for 2000. The -5.081 coefficient on log of per capita GDP in column one indicates that 10 percent higher per capita national income is associated with a 0.51 percent lower ratio of excise to total taxes. Since the mean ratio of excise to total taxes is 11.1 percent, 10 percent higher per capita income is associated with a 4.6 percent decline in excise tax collections. Even among wealthy countries, those with higher incomes rely somewhat less heavily than others do on excise taxes - or, to put the same matter differently, rely rather more heavily on income and other taxes.

The regression reported in the second column of Table 5 explains the fraction of excise taxes in total tax collections as a function of the extent to which the central 
government accounts for a country's total - central plus subnational - expenditures. The mean of this centralization measure is 72.3 percent in the sample of OECD countries. The 0.168 coefficient in column two implies that centralized governments rely more heavily on excise taxes than do other countries, such as the United States, that have decentralized structures. The coefficient implies that a 10 percent greater share of central government spending is associated with a 1.7 percent higher ratio of excise to total taxes, roughly 15 percent of its mean value.

The regression reported in the third column of Table 5 expresses the ratio of excise taxes to total taxes as a function of economic openness, which is defined as the ratio of the sum of imports and exports to GDP. The mean value of economic openness among the 26 OECD countries is 92.6 percent, though the value for the U.S. economy with its enormous internal market is only 26.2 percent. The 0.027 coefficient in the regression indicates that greater economic openness is associated with stronger reliance on excise taxes; its magnitude implies that increasing the openness of the U.S. economy to the OECD average level would increase excise tax collections by 1.8 percent of total taxes.

The dependent variable in the regressions presented in columns 4-6 of Table 5 is the ratio of the sum of VAT and general sales tax revenue to total tax collections. This measure of reliance on general consumption taxation has a mean of 24.2 percent for the sample of 25 OECD countries in 2000. The independent variables are the same as those in columns 1-3. The -16.909 coefficient in column four implies that 10 percent higher per capita national income is associated with a 1.69 percent lower ratio of general consumption taxes to total taxes, a decline of 7 percent of its mean value. The 0.374 
coefficient in column five implies that a 10 percent greater share of central government spending is associated with a 3.7 percent higher ratio of general consumption taxes to total taxes, representing 15 percent of its mean value. The 0.030 coefficient in column six, while not statistically significant, suggests that greater economic openness is associated with stronger reliance on general consumption taxes.

The regressions presented in columns one and two of Table 6 repeat the regressions reported in Table 5, except that they use multivariate specifications that include all three independent variables. The results are similar to those implied by Table 5 , though the magnitude of the effect of government centralization is diminished by roughly half in moving to the multivariate specifications. The dependent variable in the regression reported in column three of Table 6 is the ratio of the sum of excise taxes and general consumption taxes to total tax collections; this variable has a mean of 34.4 percent (though a U.S. value of only 13.9 percent). The estimated -9.183 coefficient in column three implies that this measure of consumption taxation is negatively affected by per capita income, though this is not statistically significant. The estimated 0.404 coefficient implies that a ten percent greater share of central government spending is associated with a 4.0 percent higher ratio of consumption taxes to total taxes, and the 0.043 coefficient on economic openness suggests that greater openness likewise leads to greater reliance on consumption taxes.

The regressions presented in Tables 5 and 6 display patterns in which highincome countries, those with decentralized political structures, and those with economies that have relatively lower levels of international trade rely relatively little on consumption taxes. However, the magnitudes of the coefficients are not enough to explain the U.S. 
avoidance of explicit consumption taxes. The regressions in Table 6 were re-run without data for the United States, and the resulting coefficient estimates (which do not differ much from those reported in Table 6) used to predict U.S. values of the dependent variables. The differences between predicted and actual U.S. consumption taxes indicate that, even after controlling for observable country differences, the United States has unusually low rates of consumption taxation. The most sizable effect appears in the ratio of excise taxes to total taxes, where the predicted value of 6.2 percent for the United States greatly exceeds the actual U.S. ratio of 2.4 percent. This difference largely reflects the very low gasoline tax rates in the United States. There is a more modest difference between the predicted 12.2 percent ratio of U.S. VAT plus sales taxes to total taxes and the actual ratio of 11.5 percent, but again a significant difference between the predicted 19.7 percent ratio of aggregate consumption taxes to total taxes and the actual U.S. ratio of 13.9 percent. Controlling for economic conditions and the U.S. version of federalism does not dispel the impression that the low rates of consumption taxation in the United States involve some anomalous political choices.

\section{Shifting Toward Consumption Taxes?}

The United States could shift toward collecting a greater share of its taxes in the form of consumption taxes in several ways: by reforming its income tax to reduce the taxation of capital income; by enacting a value-added tax and using the revenue to reduce capital income taxation; or by expanding its current consumption taxes.

The United States income tax has recently taken some mild steps in the direction of consumption taxation by exempting from tax some portions of the return to saving. 
Since all income must be either consumed or saved, completely exempting saving (or, what is equivalent, the return to saving) from taxation would mean that only consumption is taxed. Permitting individuals to accumulate pension assets tax-free, and to use taxpreferred savings accounts and other devices to shelter some portion of income derived from saving, moves the system toward taxing consumption. While corporate income in the United States continues to be taxed at high rates by international standards, the 2003 reductions in personal taxes on dividend income, together with favorable taxation of long-term capital gains, attenuates some of the effect at the personal level.

Despite these recent efforts to reduce the taxation of capital income, the U.S. federal government refuses to embrace explicit consumption taxation as embodied in a value-added tax. The President's Advisory Panel on Federal Tax Reform (2005) proposed a new "Growth and Investment Tax" with many consumption tax features, including cash-flow business taxation and significantly reduced individual taxation of capital income, but even this proposal retains some capital income taxation, and the Panel report stopped short of recommending a new VAT alternative for the United States. Broad-based consumption taxes such as value-added taxes clearly have enormous international appeal, and they do not affect the return to saving and investing as long as tax rates do not change over time. In contrast, income taxes, such as corporate income taxes, and personal income taxes that include returns to saving and investing, are extremely distortionary, since their effects compound over time. As a consequence, efficient tax configurations typically entail zero capital income taxation over long time horizons, since there exist much more efficient alternatives with the same distributional properties as capital taxes. 
The evidence surveyed in Auerbach and Hines (2002), along with the more recent calculations of Feldstein (2006), suggests that the average efficiency cost associated with raising one dollar of government revenue with commonly used U.S. tax instruments may be as high as 75 cents or more, with the deadweight loss of capital income taxes significantly higher than the average. Countries exposed to elastic international capital flows have separate incentives not to attempt to tax capital income, as these countries must offer international investors market rates of return, from which it follows that any attempt to tax foreigners simply distorts the economy without extracting greater resources from foreigners (Gordon and Hines, 2002). There is extensive evidence (surveyed in Hines, 1999) that high source-based capital taxes, such as corporate income taxes, significantly distort local economies by discouraging foreign investment. Since the costs of taxing foreigners are borne by domestic factors in the form of lower wages and land prices, and these costs include deadweight losses due to inefficient taxation, domestic residents are made better off by removing any taxes on foreign investors and instead directly taxing the returns to local factors of production. Hence it is perhaps not surprising that governments around the world embrace VATs and other consumption taxes that do not have these features.

One of the political obstacles that a VAT or any other broad based consumption tax must overcome in the United States is the concern, in some circles, that such taxes are too efficient at raising revenue, that they too easily accommodate big government. While there is little econometric support for the notion that the adoption of a VAT encourages government growth (for example, Metcalf, 1995, p. 136), it is noteworthy that Michigan, the only state in the country to use a VAT instead of a corporate income tax, taxed 
businesses more heavily with its VAT than did any other state with corporate income taxes during in the years when Michigan's VAT was in place (Hines, 2003, p. 607).

A second important political obstacle facing any new U.S. VAT proposal is distributional, grounded in the argument that a VAT would be significantly less progressive than the current U.S. income tax system. The relevance of this concern depends entirely on what other changes in the U.S. tax system would accompany the adoption of a VAT. The U.S. government could adopt a VAT and simultaneously adjust the personal income tax schedule to produce a tax system with the same, or even more progressive, distributional features as the current tax system. For example, Michael Graetz (2002) has proposed one version of such a comprehensive U.S. tax reform, that includes a $15 \%$ VAT, elimination of personal taxes on the first $\$ 100,000$ of income, reduction of payroll taxes for low-income workers, and other features designed to maintain progressivity.

If dramatic changes to income taxes or implementation of a VAT encounter political obstacles, another approach to swinging the U.S. tax system toward a greater emphasis on consumption taxation would be to increase state sales taxes or state and federal excise taxes. States already rely heavily on sales and excise taxes, and their relatively small revenue requirements give states considerably less scope for comprehensive consumption-oriented tax reform than is the case for the federal government. But greater federal reliance on excise taxes would require addressing some difficult theoretical, distributional, and practical concerns. 
The received theoretical wisdom is that excise taxes can correct market failures that accompany externalities, by having the tax rates set equal to marginal external damages caused by consumption of the taxed good. This insight, commonly attributed to Pigou (1920), suggests that excise taxes may be used in lieu of other regulatory mechanisms to discourage activities that consumers would otherwise overdo. Strict application of this logic requires sensitive tailoring of excise taxes to reflect differences in marginal damages over time and between situations, but even in the absence of perfect design, excise taxes can mitigate the problems that would otherwise accompany congestion, pollution, and other externalities.

There is considerable controversy over the level of excise taxation necessary to correct externalities in practice. Assuming that the government is unable to distinguish taxes on a customer's first drink of alcohol, which has no external costs, from taxes on the seventh drink just prior to driving a car, which has considerable external costs, appropriate corrective policy entails a compromise between correcting externalities and distorting ordinary consumer decisions. A similar logic applies to the costs of smoking, air pollution, traffic congestion, and other externalities. Cnossen and Smart (2005) conclude from their survey of the literature that a purely externality-correcting tobacco tax would be much lower than existing tobacco taxes in Europe and the United States, whereas Pogue and Sgontz (1989) maintain that externality-correcting alcohol taxes would be twice the existing U.S. levels, and Kenkel (1996) argues that U.S. alcohol taxes would need to be four to five times current levels properly to correct for externalities. Gasoline taxes serve both to reduce traffic congestion and to improve air and climate 
quality, on the basis of which Parry and Small (2004) find that externality-correcting gasoline tax rates for the United States are slightly more than double current tax levels.

There is a separate question of the appropriate role, if any, of excise taxes in discouraging the consumption of goods that may not have external effects, but are nonetheless harmful to the individuals who consume them. Examples of such goods include tobacco products, alcohol, and food with poor nutritional content (or any food in excess of healthy levels). ${ }^{2}$ Irrational consumers may begin consuming these items without fully appreciating the regret they will experience years later, and experience what have been called "internalities." In such settings, there could be a role for excise taxation to help consumers by making it more expensive, and therefore less likely, to start early on the path of overconsumption. O'Donoghue and Rabin $(2003,2006)$ analyze optimal excise taxation in settings in which individuals have self-control problems (but governments do not), and Gruber and Koszegi (2004) and Gruber and Mullainathan (2005) offer applications to cigarette taxes.

One concern frequently expressed about excise taxation is the potential regressivity of the resulting tax burdens. ${ }^{3}$ The concern is that because the poor tend to spend higher fractions of their income than do the wealthy, taxes based on expenditure rather than income will put greater relative burdens on low-income individuals. There are two important considerations to bear in mind in evaluating the distributional effects of

\footnotetext{
${ }^{2}$ These goods may also be responsible for externalities, through such mechanisms as second-hand smoke, traffic accidents associated with alcohol, and government policies that provide benefits to individuals and families harmed by overconsumption. Such externalities carry straightforward implications for corrective taxation, but there remains the question of whether any additional tax is warranted due to the failure of individual optimization.
} 
excise taxation. The first is that the progressivity of excise taxes should be evaluated from a lifetime perspective; for example, it would be a mistake to infer from the fact that affluent retirees might have little current income but significant current expenditures that excise taxes are regressive. Since lifetime (including intergenerational) consumption tracks lifetime income very closely, flat-rate excise taxes look much like flat-rate income taxes from a progressivity standpoint. Certain excise taxes might differentially impact certain groups in the population, for example excise taxes designed to protect the environment that might impose greater relative burdens on low-income individuals. Poterba $(1989,1991)$ and Walls and Hanson (1999) analyze U.S. gasoline taxes from the standpoint of lifetime incidence, finding that gasoline consumption rises more than proportionally with affluence over much of the range of total spending, suggesting that gasoline taxes are progressive, albeit less so than income taxes.

The second, and more important, consideration is that, as with a value-added tax, excise tax burdens must be understood in the context of the broader tax system. If, in the course of pursuing environmental or other objectives, a country adopts excise taxes that unduly burden one segment of the income distribution, the government can, if it wishes, undo this distributional shift by adjusting its income tax schedule. As Kaplow (2006) notes, selecting excise taxes can for this reason be done without connecting distributional and other policy objectives. ${ }^{4}$ The same argument implies that excise taxes on luxury items - such as the U.S. federal taxes on expensive furs and jewelry, luxury cars,

\footnotetext{
${ }^{3}$ Excise taxes also raise enforcement concerns, as do all taxes. In the United Kingdom, which boasts the highest cigarette taxes in Europe, one in five cigarettes is purchased on the black market (Cnossen and Smart, 2005, p. 45).

${ }^{4}$ This argument, which applies the findings of Atkinson and Stiglitz (1976), requires that preferences be weakly separable between consumption and leisure, a restriction that, while unlikely to be strictly satisfied, does little to reduce the power of the argument.
} 
personal aircraft, and yachts, introduced in 1990 and since expired - are generally less

effective, and indeed never more effective, at redistributing income than are income tax alternatives.

Naturally, practical implementation of excise taxation differs from the ideal tax systems analyzed in theory. For example, there is ample international evidence that gasoline taxes and other taxes intended to protect the environment are not designed in ways that achieve maximal environmental protection for any given level of total tax burden (for example, Barde and Braathen, 2005). In part, this reflects that consumption of the same good in different places or at different times may have quite divergent environmental impact, while as a practical matter it is extremely difficult to design tax rates that fit these differences. In addition, political processes offer no guarantees that environmental taxes will be set with only environmental considerations in mind.

Widespread use of excise taxation focuses business interests in reducing tax rates on the commodities that they sell, thereby encouraging extensive political lobbying and the problems that accompany it. Moreover, the tax burdens that accompany excise taxes may or may not be offset by compensating income tax changes. Political infighting need not produce harmonious or efficient constellations of taxes.

\section{Conclusion}

Throughout most of American history, federal and state governments have relied on excise taxes to collect significant revenues, with the modern era a notable exception. The absence of value-added taxation in the United States, together with modest state sales taxes and an unwillingness to intrude on individuals' lives by imposing "sin" taxes at 
rates resembling those of other countries, leaves the United States taxing consumption very lightly by international standards.

Heavy American reliance on income rather than consumption taxation has not served the United States well. The inefficiency associated with taxing the return to capital means that the tax system reduces investment in the United States and distorts intertemporal consumption by Americans, meanwhile discouraging U.S. labor supply no less than would a consumption tax alternative. While the economic logic of consumption taxation is compelling even for a closed economy, it is even more powerful for an open economy exposed to the world capital market. Consumption taxes in the form of excises can be designed to help protect the environment and control other externalities, whereas it is much more difficult to pursue the same goals with income taxes. Excise taxes can also serve the function of more closely aligning tax burdens with the benefits that taxpayers receive from certain government services. There are understandable concerns about the distributional consequences of consumption taxation, but a system that relies heavily on consumption taxes, particularly if accompanied by an income tax, can be made as progressive as any income tax the United States would realistically want to adopt.

Will the United States, in time, come to resemble more closely the rest of the world, perhaps by adopting higher gasoline taxes or a national value-added tax? The opposition to higher gasoline taxes in the United States seems powerful and bipartisan. As to the prospects for a value-added tax, the old line is that the United States does not have a value-added tax because Democrats think it is regressive, and Republicans think it is too easy to raise revenue with one. The country will get a value-added tax, the line continues, once Republicans realize that it is regressive and Democrats realize that it is 
easy to raise revenue with one. Perhaps more likely is that the United States will seriously entertain new consumption-oriented tax alternatives only when confronting a financial crisis that admits no easy solution and cannot be ignored. After all, the need to finance sudden wartime expenditures accounts for many of the past innovations in U.S. taxation. But the political system may yet prove itself capable of creating periodic crises even in the absence of external enemies, thereby furnishing opportunities to consider adopting tax measures that have proved attractive in the rest of the world. 


\section{References}

Atkinson, Anthony B. and Joseph E. Stiglitz, The design of tax structure: Direct versus indirect taxation, Journal of Public Economics, July-August 1976, 6 (1-2), 55-75.

Auerbach, Alan J. and James R. Hines Jr., Taxation and economic efficiency, in Alan J. Auerbach and Martin Feldstein eds., Handbook of public economics, volume 3 (Amsterdam: North-Holland, 2002), 1347-1421.

Barde, Jean-Philippe and Nils Axel Braathen, Environmentally related taxes, in Sijbren Cnossen ed., Theory and practice of excise taxation (Oxford, UK: Oxford University Press, 2005), 120-154.

Barthold, Thomas A., Issues in the design of environmental excise taxes, Journal of Economic Perspectives, Winter 1994, 8 (1), 133-151.

Cnossen, Sijbren and Michael Smart, Taxation of tobacco, in Sijbren Cnossen ed., Theory and practice of excise taxation (Oxford, UK: Oxford University Press, 2005), 2055.

Dewey, Davis Rich, Financial history of the United States, $3^{\text {rd }}$ ed., New York: Longmans Green, 1907).

Ebrill, Liam, Michael Keen, Jean-Paul Bodin, and Victoria Summers, The modern VAT (Washington, DC: International Monetary Fund, 2001).

Ely, Richard T., Taxation in American states and cities (New York: Crowell, 1888).

Feldstein, Martin, The effects of taxes on efficiency and growth, NBER Working Paper No. 12201, May 2006.

Francis, Brian, Gasoline excise taxes, 1933-2000, Statistics of Income Bulletin, Winter 2000, 20 (3), 140-146.

Fullerton, Don, Why have separate environmental taxes? in James M. Poterba ed., Tax Policy and the Economy, volume 10 (Cambridge, MA: MIT Press, 1996), 33-70.

Gordon, Roger H. and James R. Hines Jr., International taxation, in Alan J. Auerbach and Martin Feldstein eds., Handbook of public economics, volume 4 (Amsterdam: North-Holland, 2002), 1935-1995.

Graetz, Michael J., 100 million unnecessary returns: A fresh start for the U.S. tax system, Yale Law Journal, November 2002, 112 (2), 261-310.

Gruber, Jonathan and Daniel M. Hungerman, Faith-based charity and crowd out during the Great Depression, NBER Working Paper No. 11332, May 2005. 
Gruber, Jonathan and Botond Koszegi, Tax incidence when individuals are time inconsistent: The case of cigarette excise taxes, Journal of Public Economics, August 2004, 88 (9-10), 1959-1988.

Gruber, Jonathan and Sendhil Mullainathan, Do cigarette taxes make smokers happier? Advances in Economic Analysis and Policy, 2005, 5 (1), Article 4.

Haig, Robert Murray and Carl Shoup, The sales tax in the American states (New York: Columbia University Press, 1934).

Hines, James R., Jr., Lessons from behavioral responses to international taxation, National Tax Journal, June 1999, 52 (2), 305-322.

Hines, James R., Jr., Michigan's flirtation with the Single Business Tax, in Charles L. Ballard et al. eds, Michigan at the millennium (East Lansing, MI: Michigan State University Press, 2003), 603-628.

Hu, Tan Yuan, The liquor tax in the United States, 1791-1947 (New York: Columbia University Press, 1950).

Kaplow, Louis, Optimal control of externalities in the presence of income taxation, NBER Working Paper No. 12339, June 2006.

Kenkel, Donald S.,New estimates of the optimal tax on alcohol, Economic Inquiry, April 1996, 34 (2), 296-319.

Merrill, Peter R. and Ada S. Rousso, Federal environmental taxation, Proceedings of the National Tax Association Annual Conference, 1991, 83, 191-198.

Metcalf, Gilbert E., Value-added taxation: A tax whose time has come? Journal of Economic Perspectives, Winter 1995, 9 (1), 121-140.

O’Donoghue, Ted and Matthew Rabin, Studying optimal paternalism, illustrated by a model of sin taxes, American Economic Review, May 2003, 93 (2), 186-191.

O’Donoghue, Ted and Matthew Rabin, Optimal sin taxes, Journal of Public Economics, November 2006, 90 (10-11), 1825-1849.

Organisation for Economic Cooperation and Development, Consumption tax trends, 2004 edition (Paris: OECD, 2005).

Parry, Ian W.H. and Kenneth A. Small, Does Britain or the United States have the right gasoline tax? Resources for the Future Discussion Paper 02-12 rev., September 2004.

Pigou, A.C., The economics of welfare (London: Macmillan, 1920).

Pogue, Thomas F. and Larry G. Sgontz, Taxing to control social costs: The case of alcohol, American Economic Review, March 1989, 79 (1), 235-243. 
Poterba, James M., Lifetime incidence and the distributional burden of excise taxes, American Economic Review, May 1989, 79 (2), 325-330.

Poterba, James M., Is the gasoline tax regressive? in David Bradford ed., Tax Policy and the Economy, volume 5 (Cambridge, MA: MIT Press, 1991), 145-164.

President's Advisory Panel on Federal Tax Reform, Simple, fair and pro-growth: Proposals to fix America's tax system (Washington, DC: U.S. Government Printing Office, November 2005).

Statistics of Income, Selected historical and other data, Statistics of Income Bulletin, Winter 2005, 25 (3), 163-233.

Sumner, William Graham, The financier and the finances of the American Revolution (New York: Dodd Mead, 1891).

Walls, Margaret and Jean Hanson, Distributional aspects of an environmental tax shift:

The case of motor vehicle emissions taxes, National Tax Journal, March 1999, 52 (1), 53-65. 


\section{Table 1}

\section{Current Major U.S. Federal Excise Taxes}

Total collections: $\$ 71.8$ billion in 2004

\section{Of which:}

Gasoline, gasohol, diesel fuel

$\$ 32.6 \mathrm{~b}$

Telephone tax

$\$ 5.8 \mathrm{~b}$

Air transportation tax

$\$ 6.0 \mathrm{~b}$

Tobacco

$\$ 7.9 \mathrm{~b}$

Distilled spirits

$\$ 4.3 \mathrm{~b}$

Wine

$\$ 0.8 \mathrm{~b}$

Beer

$\$ 3.6 \mathrm{~b}$

Trucks, trailers, and tractors

$\$ 2.2 \mathrm{~b}$

Use of international air travel facilities

$\$ 1.6 \mathrm{~b}$

Use tax on heavy vehicles

$\$ 0.9 \mathrm{~b}$

Highway tires

$\$ 0.4 \mathrm{~b}$

Sports equipment

$\$ 0.1 \mathrm{~b}$

Firearms and ammunition

$\$ 0.2 \mathrm{~b}$

Unclassified

$\$ 0.9 \mathrm{~b}$

Source: Statistics of Income (2005). 


\begin{tabular}{|c|c|c|c|}
\hline \multicolumn{4}{|c|}{ Table 2: Federalism and Excise Tax Differences, 2006} \\
\hline \multicolumn{2}{|c|}{ Gasoline taxes (per gallon) } & \multicolumn{2}{|c|}{ Cigarette taxes (per pack) } \\
\hline \multicolumn{2}{|c|}{ "High" tax states } & \multicolumn{2}{|c|}{ "High" tax states } \\
\hline Wisconsin & $32.9 \not$ & Rhode Island & $\$ 2.46$ \\
\hline Pennsylvania & $31.2 \not$ & New Jersey & $\$ 2.40$ \\
\hline Rhode Island & $31 \notin$ & Washington & $\$ 2.03$ \\
\hline Washington & $31 \notin$ & Michigan & $\$ 2.00$ \\
\hline North Carolina & $30.15 \not$ & Maine & $\$ 2.00$ \\
\hline \multicolumn{2}{|c|}{ “Low" tax states } & \multicolumn{2}{|c|}{ "Low" tax states } \\
\hline Georgia & $15.3 \not$ & Kentucky & $30 \phi$ \\
\hline Florida & $14.9 \not$ & Virginia & $30 \varnothing$ \\
\hline New Jersey & $14.5 \not$ & Tennessee & $20 \phi$ \\
\hline Wyoming & $14 \not$ & Mississippi & $18 \varnothing$ \\
\hline \multirow[t]{2}{*}{ Alaska } & $8 \phi$ & Missouri & $17 \varnothing$ \\
\hline & & South Carolina & $7 \phi$ \\
\hline U.S. state average & $21.57 \varnothing$ & & $91.7 \varnothing$ \\
\hline $\begin{array}{l}\text { U.S. federal } \\
\text { government }\end{array}$ & $18.4 \varnothing$ & & $39 \varnothing$ \\
\hline & & & \\
\hline
\end{tabular}




\section{Table 3: Gasoline and Alcohol Excise Taxes in OECD Countries, 2003}

Tax per 1000 liters of unleaded gasoline

\begin{tabular}{|l|c|l|c|}
\hline United Kingdom & $\$ 758.97$ & Norway & $\$ 7855.90$ \\
\hline Germany & 687.29 & Iceland & 6389.57 \\
\hline Norway & 670.06 & Sweden & 5778.25 \\
\hline Finland & 650.75 & Ireland & 4121.64 \\
\hline Netherlands & 647.37 & Denmark & 3889.05 \\
\hline Korea, Republic of & 627.65 & Turkey & 3604.06 \\
\hline France & 618.72 & United Kingdom & 3151.90 \\
\hline Italy & 568.99 & Finland & 2966.53 \\
\hline Denmark & 566.53 & Switzerland & 2100.24 \\
\hline Portugal & 548.78 & Netherlands & 1863.93 \\
\hline Sweden & 542.78 & Belgium & 1744.10 \\
\hline Switzerland & 529.55 & France & 1522.65 \\
\hline Turkey & 525.76 & Germany & 1368.28 \\
\hline Belgium & 518.28 & Poland & 1146.20 \\
\hline Iceland & 484.06 & New Zealand & 1134.45 \\
\hline Japan & 470.28 & Luxembourg & 1093.30 \\
\hline Hungary & 461.51 & Austria & 1050.10 \\
\hline Austria & 427.39 & Greece & 953.49 \\
\hline Ireland & 421.47 & Portugal & 943.12 \\
\hline Luxembourg & 400.17 & United States & 920.00 \\
\hline Spain & 390.31 & Czech Republic & 779.69 \\
\hline Poland & 390.23 & Spain & 719.48 \\
\hline Czech Republic & 361.19 & Canada & 703.85 \\
\hline Slovak Republic & 314.09 & Italy & 677.69 \\
\hline Greece & 310.83 & Slovak Republic & 633.25 \\
\hline Australia & 214.17 & Hungary & 7.45 \\
\hline New Zealand & 189.71 & & \\
\hline United States & 112.80 & & \\
\hline Canada & 63.61 & & \\
\hline Mexico & 0.07 & & \\
\hline
\end{tabular}

Note: the table presents excise taxes (in U.S. dollars) on unleaded gasoline and on distilled alcohol in OECD countries in 2003. Source: OECD (2005). 
Table 4: VAT Rates and General Consumption Taxes, 2000

\begin{tabular}{|c|c|c|c|}
\hline \multicolumn{2}{|c|}{ Value Added Tax Rates (percent) } & \multicolumn{2}{|c|}{ General Consumption Taxes/Total Taxes } \\
\hline Denmark & 25.0 & Iceland & $29.7 \%$ \\
\hline Hungary & 25.0 & Hungary & 26.1 \\
\hline Sweden & 25.0 & New Zealand & 24.7 \\
\hline Iceland & 24.5 & Turkey & 24.2 \\
\hline Norway & 23.0 & Portugal & 23.2 \\
\hline Slovak Republic & 23.0 & Ireland & 23.1 \\
\hline Czech Republic & 22.0 & Slovak Republic & 22.3 \\
\hline Finland & 22.0 & Poland & 22.0 \\
\hline Poland & 22.0 & Greece & 21.8 \\
\hline Belgium & 21.0 & Denmark & 19.5 \\
\hline Ireland & 21.0 & Norway & 19.2 \\
\hline France & 20.6 & Austria & 18.8 \\
\hline Austria & 20.0 & Mexico & 18.7 \\
\hline Italy & 20.0 & Germany & 18.4 \\
\hline Greece & 18.0 & Czech Republic & 18.3 \\
\hline Netherlands & 17.5 & United Kingdom & 18.2 \\
\hline United Kingdom & 17.5 & Spain & 17.5 \\
\hline Portugal & 17.0 & Finland & 17.4 \\
\hline Turkey & 17.0 & Netherlands & 17.4 \\
\hline Germany & 16.0 & Korea, Republic of & 17.0 \\
\hline Spain & 16.0 & France & 16.8 \\
\hline Luxembourg & 15.0 & Sweden & 16.8 \\
\hline Mexico & 15.0 & Belgium & 16.3 \\
\hline New Zealand & 12.5 & Italy & 15.4 \\
\hline Australia & 10.0 & Luxembourg & 15.0 \\
\hline Korea, Republic of & 10.0 & Canada & 14.3 \\
\hline Switzerland & 7.5 & Switzerland & 13.1 \\
\hline Canada & 7.0 & Australia & 12.1 \\
\hline Japan & 5.0 & Japan & 8.9 \\
\hline United States & 0.0 & United States & 7.6 \\
\hline
\end{tabular}

Note: the second column of the table presents value added tax rates in 2000; the fourth column presents ratios of general consumption taxes to total taxes (measured in percentages) for 2000. Sources: International Monetary Fund and OECD (2005). 
Table 5

Impact of Country Characteristics on Structure of Tax Revenue for OECD Countries, 2000

\begin{tabular}{|c|c|c|c|c|c|c|}
\hline \multirow[t]{2}{*}{$\begin{array}{l}\text { Dependent } \\
\text { Variable: }\end{array}$} & \multicolumn{3}{|c|}{$\begin{array}{c}\text { Excise Revenue as a percentage of } \\
\text { Total Tax Revenue }\end{array}$} & \multicolumn{3}{|c|}{$\begin{array}{c}\text { VAT and Sales Revenue as a percentage of } \\
\text { Total Tax Revenue }\end{array}$} \\
\hline & (1) & (2) & (3) & (4) & (5) & (6) \\
\hline Constant & $\begin{array}{c}61.756 \\
(24.688)\end{array}$ & $\begin{array}{l}-1.072 \\
(2.421)\end{array}$ & $\begin{array}{c}8.564 \\
(1.352)\end{array}$ & $\begin{array}{l}193.416 \\
(31.814)\end{array}$ & $\begin{array}{l}-2.890 \\
(7.867)\end{array}$ & $\begin{array}{l}21.400 \\
(4.036)\end{array}$ \\
\hline $\begin{array}{l}\text { Log of Per } \\
\text { Capita GDP }\end{array}$ & $\begin{array}{l}-5.081 \\
(2.500)\end{array}$ & & & $\begin{array}{r}-16.909 \\
(3.262)\end{array}$ & & \\
\hline $\begin{array}{l}\text { Degree of Govt. } \\
\text { Centralization }\end{array}$ & & $\begin{array}{c}0.168 \\
(0.031)\end{array}$ & & & $\begin{array}{c}0.374 \\
(0.104)\end{array}$ & \\
\hline $\begin{array}{l}\text { Openness of } \\
\text { Economy }\end{array}$ & & & $\begin{array}{c}0.027 \\
(0.011)\end{array}$ & & & $\begin{array}{c}0.030 \\
(0.040)\end{array}$ \\
\hline $\begin{array}{l}\text { No. of } \\
\text { Observations }\end{array}$ & 26 & 26 & 26 & 25 & 25 & 25 \\
\hline R-squared & 0.318 & 0.463 & 0.153 & 0.482 & 0.373 & 0.031 \\
\hline
\end{tabular}

Notes: $\quad{ }^{1)}$ Robust standard errors are listed in parentheses.

2) Per Capita GDP is measured in current U.S. dollars, and Openness of Economy is measured as the sum of imports and exports divided by GDP. Data are reported by the Penn World Tables edition 6.1. Degree of Govt. Centralization is measured as central government expenditure divided by the sum of central, state, and local government expenditure, with data obtained from the IMF Government Finance Statistics, January 2006 edition. The dependent variables measure specific tax revenues collected by the central (and where available state and local) government, divided by the sum of central, state, and local government tax collections. Data are obtained from the January 2006 edition of the IMF Government Finance Statistics. 
Table 6

Determinants of Structure of Tax Revenue for OECD Countries, 2000

\begin{tabular}{|c|c|c|c|}
\hline Dependent Variable: & $\begin{array}{c}\text { Excise/ } \\
\text { Total Taxes }\end{array}$ & $\begin{array}{c}\text { (VAT+Sales)/ } \\
\text { Total Taxes }\end{array}$ & $\begin{array}{c}\text { (Excise+VAT+Sales)/ } \\
\text { Total Taxes }\end{array}$ \\
\hline & (1) & (2) & (3) \\
\hline Constant & $\begin{array}{c}44.437 \\
(21.033)\end{array}$ & $\begin{array}{l}152.476 \\
(24.786)\end{array}$ & $\begin{array}{c}92.797 \\
(109.754)\end{array}$ \\
\hline Log of Per Capita GDP & $\begin{array}{l}-4.231 \\
(1.920)\end{array}$ & $\begin{array}{l}-14.293 \\
(2.239)\end{array}$ & $\begin{array}{l}-9.183 \\
(9.898)\end{array}$ \\
\hline $\begin{array}{l}\text { Degree of Govt. } \\
\text { Centralization }\end{array}$ & $\begin{array}{c}0.091 \\
(0.037)\end{array}$ & $\begin{array}{c}0.165 \\
(0.104)\end{array}$ & $\begin{array}{c}0.404 \\
(0.182)\end{array}$ \\
\hline Openness of Economy & $\begin{array}{c}0.025 \\
(0.010)\end{array}$ & $\begin{array}{c}0.030 \\
(0.016)\end{array}$ & $\begin{array}{c}0.043 \\
(0.029)\end{array}$ \\
\hline Observations & 26 & 25 & 26 \\
\hline R-squared & 0.654 & 0.602 & 0.484 \\
\hline $\begin{array}{l}\text { R) Robust standard erro } \\
\text { 2) Per Capita GDP is m } \\
\text { by GDP. Data are re } \\
\text { expenditure divided } \\
\text { Finance Statistics, Ja } \\
\text { available state and lo } \\
\text { the January } 2006 \text { edi }\end{array}$ & $\begin{array}{l}\text { arentheses. } \\
\text { ent U.S. dolla } \\
\text { nnn World Tal } \\
\text { entral, state, a } \\
\text { ion. The depe } \\
\text { it, divided by } \\
\text { Government }\end{array}$ & $\begin{array}{l}\text { nomy is meass } \\
\text { of Govt. Centr } \\
\text { penditure, with } \\
\text { e specific tax r } \\
\text {, and local gov }\end{array}$ & $\begin{array}{l}\text { of imports and exports divided } \\
\text { sured as central government } \\
\text { rom the IMF Government } \\
\text { ed by the central (and where } \\
\text { lections. Data are obtained from }\end{array}$ \\
\hline
\end{tabular}

